\title{
ANALISIS KEBUTUHAN DAN SEBARAN FASILITAS PENDIDIKAN TINGKAT SMP DAN SMA DI KABUPATEN SOLOK SELATAN
}

\author{
Widia Lolina Fidani ${ }^{1}$, Widya Prarikeslan ${ }^{2}$ \\ Program Studi Pendidikan Geografi, \\ Fakultas Ilmu Sosial, Universitas Negeri Padang \\ Email: widia.lovi@gmail.com
}

\begin{abstract}
ABSTRAK
Tujuan penelitian ini adalah 1) mengevaluasi ketersediaan fasilitas pendidikan tingkat SMP dan SMA di kabupaten Solok Selatan, 2) kebutuhan fasilitas pendidikan tingkat SMP dan SMA masa sekarang dan 20 tahun mendatang, 3) sebaran dan jangkauan pelayanan fasilitias pendidikan kabupaten Solok Selatan. Pada penelitian ini untuk mencapai tujuan pertamadigunakan analisis tingkat pelayanan fasilitas pendidikan dengan mengukur tingkat kebutuhan dan tingkat keterisian. Tujuan ke-2 menggunakan metode proyeksi penduduk, dan tujuan ke-3 menggunakan metode buffer.Hasil penelitian menunjukkan 1) evaluasi ketersediaan fasilitias pendidikan eksisting tingkat SMP dari pemenuhan kebutuhan semua kecamatan masuk kedalam kategori cukup, sementara untuk tingkat SMA lima kecamatan berkategori cukup, dua kecamatan berkategori kurang yaitu Kecamatan Sangir Balai Janggo dan Pauh Duo. Tingkat keterisian pada tingkat SMP semua kecamatan masuk kategori kurangbegitupun hal nya untuk tingkat SMA.2) Kabupaten Solok Selatan saat sekarang membutuhkan 43SMPdan 15 SMA.Sementarauntuk 20 tahun yang akan datang membutuhkan 127 SMP dan 41 SMA. 3) Hasil sebaran serta jangkauan pelayanan tingkat SMP setelah di buffer masih ada permukiman penduduk yang berada di luar jangkauan pelayanan sehingga pelayanan sekolah yang ada yaitu berada di kecamatan Koto Parik Gadang Di Ateh, Sangir Jujuan, Sangir Batang Hari, dan Sangir Balai Janggo.
\end{abstract}

Kata Kunci: (Ketersediaan; Kebutuhan; Sebaran Fasilitas Pendidikan)

\begin{abstract}
The purpose of this study was to determine the evaluation of the availability of junior and senior hinght school education facilities in south solok district, to find out what the junior and senior hight school level needs for the present and 20 years to come, and to know the distribution and coverage of education facilities in south solok district. In this study to achieve the firs goal the method used is to see the levelof service of educational facilities by measuring the levelof need and level of filling, for the second goal using the method of population projection for the next 20 years, the the third goal using buffering method. The result of this study indicate that in order to evaluate the availability of junior high school education facilities in terms of meeting all of sub-districts with good categories. While for the hight school level there are five sub-district with good categories, two sub-districts categoris is a bad. From the results of the analysis of the needs for now (2019), the southern solok districtfor junior hight school requeres 43 school units, while for high schools it requires 15 units, while the need for the nex years for junior high school requires 127 school units, and for high school 41 school units. For the result distribution and coverage of the service level of the SMP after being buffered in turns out there are range of school services that exi, namely in the sub-district Koto Parik Gadang Di Ateh, Sangir Jujuan, Sangir Batang Harti and Sangir Balai Janggo.
\end{abstract}

Keywords: (Availability; Needs; Distribution of Educational Facilities)

\footnotetext{
${ }^{1}$ Mahasiswa program studi Pendidikan Geografi

${ }^{2}$ Dosen Jurusan Geografi Fakultas Ilmu Sosial Negeri Padang
} 


\section{PENDAHULUAN}

Kualitas suatu bangsa dapat dilihat dari sumber daya manusia yang ada didalamnya melalui bidang pendidikan. Bahkan maju atau tertinggalnya suatu daerah juga turut mempertimbangkan indeks pembangunan manusianya, dan itu dapat ditinjau dari sisi pendidikan. Salah satu yang mempengaruhi kualitas pendidikan adalah fasilitas pendidikan itu sendiri.Fasilitas pendidikan tak terlepas dari sarana dan prasarana yang menunjang pendidikan. Sarana pendidikan adalah peralatan dan perlengkapan yang secara langsung dipergunakan dan menunjang proses pendidikan, khususnya proses belajar mengajar seperti gedung, ruang kelas, meja, kursi, serta alat-alat media pengajaran (Mulyasa, 2005:49)

Permendiknas No 24 tahun 2004 menetapkan bahwa sebuah SMP/MTs sekurang-kurangnya memiliki prasarana: 1) ruang kelas, 2) ruang perpustakaan, 3) ruang laboratorium IPA, 4) ruang pimpinan, 5) ruang guru, 6) ruang tata usaha, 7)tempat beribadah, 8) ruang konseling, 9) ruang UKS, 10) ruang organisasi, 11) jamban, 12) gudang, 13) ruang sirkulasi, 14) tempat bermain/sirkulasi. Standard untuk SMA/MA ditetapkan harus mempunyai: 1) ruang kelas, 2) ruang perpustakaan, 3) ruang laboratorium bilogi, 4) ruang laboratotium fisika, 5) ruang laboratorium kimia, 6) ruang laboratorium komputer, 7) ruang laboratorium bahasa, 8) ruang tata usaha, 9) ruang guru, 10) tempat ibadah, 11) ruang konseling, 12) ruang UKS, 13) ruang organisasi kesiswaan, 14) jamban, 15) gudang, 16) ruang sirkulasi, 17) tempat bermain/berolahraga (Usman, 2006). Berdasarkan peraturan Permendiknas No 24 tahun 2007 menyatakan bahwa untuk satu unit SMP maksimal melayani 2000 penduduk dengan 24 rombongan belajar, untuk pelayanan penduduk lebih dari 2000 jiwa akan dilakukan pembangunan sekolah baru, sedangkan untuk satu unit SMA melayani 6000 penduduk dengan maksimal 27 rombongan belajar, untuk pelayanan penduduk yang lebih dari 6000 penduduk akan dilakukan penambahan sekolah baru.

Berdasarkan lampiran Peraturan Presiden (Perpres) No 131/2015 tentang penetapan daerah tertinggal tahun 2015-2019 ditetapkan bahwa tiga kabupaten yang berstatus tertinggal pada Provinsi Sumatera Barat salah satunya adalah Kabupaten Solok Selatan.Terbukti indeks pembangunan manusia Kabupaten Solok Selatan 67,47 yang masih berada dibawah rata-rata IPM provinsi yaitu 70,73 (Sekretaris Daerah Kabupaten Solok Selatan,2018).

Fasilitas pendidikan seperti kuantitas bangunan sekolah yang masih minim dan belum memenuhi standar menjadi salah satu faktor yang memperlambat laju indeks 
pembangunan manusia di Kabupaten Solok Selatan.Badan Pusat Statistik (2019) menunjukkan jumlah penduduk kabupaten Solok Selatan tahun 2018 yaitu 169.667 jiwa sedangkan untuk SMP yang tersedia sebanyak 36 SMP Negeri serta terdapat 11 SMANegeri (Dinas Pendidikan Kabupaten Solok Selatan).

Berdasarkan ketetapan Permendiknas No 24 tahun 2007 tersebut jumlah sekolah Kabupaten Solok Selatan yang ada saat ini masih belum memenuhi kebutuhan penduduknya sesuai dengan standar yang telah ditetapkan.

Berdasarkan permasalahan tersebut penulis melakukan penelitian tentang "Analisisis Kebutuhan dan Sebaran Fasilitas Pendidikan Tingkat SMP dan SMA di Kabupaten Solok Selatan". Tujuan dari penelitian ini adalah untukmengevaluasi ketersediaan fasilitas pendidikan eksisting, kebutuhan penduduk akan fasilitas pendidikan pada masa sekarang dan 20 tahun yang akan datang, sebaran dan jangkauan pelayanan fasilitas pendidikan (tingkat SMP dan SMA).

\section{METODE}

\section{Lokasi dan waktu penelitian}

$$
\text { Penelitian dilakukan }
$$

Kabupaten Solok Selatan, Sumatera Barat. Penelitian ini dilaksanakan dalam kurun waktu 1 bulan. Data yang digunakan adalah data sekunder dari instansi terkait seperti Badan Pusat Statistik, Dinas Pendidikan Kabupaten Solok Selatan dan Dinas Pendidikan Provinsi Sumatera Barat.

Evaluasi ketersediaan fasilitas pendidikan dapat dilihat dari tingkat pelayanan fasilitas pendidikan dengan menggunakan 2 analisis yaitu analisis pemenuhan kebutuhan dan tingkat keterisian sekolah. Kebutuhan sekolah saat sekarang dan 20 tahun yang akan datang dilihat dengan metode proyeksi penduduk, dan untuk melihat sebaran serta jangkauan pelayanan itu menggunakan teknik buffer.

Tabel 1. Jenis dan sumber data

\begin{tabular}{|c|c|}
\hline No Data & Sumber \\
\hline $\begin{array}{l}\text { a. Jumlah penduduk perkecamatan, } \\
\text { b. Jumlah penduduk usia sekolah (13- } \\
\text { 15) tahun (16-18 tahun) } \\
\text { c. APM (angka partisipasi murni) }\end{array}$ & $\begin{array}{l}\text { Badan Pusat Statistik Kabupaten } \\
\text { Solok Selatan } 2018\end{array}$ \\
\hline $\begin{array}{l}\text { a. Jumlah sisiwa pada jenjang } \\
\text { pendidikan tertentu }\end{array}$ & $\begin{array}{l}\text { Dinas Pendidikan Kabupaten Solok } \\
\text { Selatan dan Dinas Pendidikan Provinsi } \\
\text { Sumatera Barat }\end{array}$ \\
\hline $\begin{array}{l}\text { a. Jumlah sekolah eksisting } \\
\text { b. Sekolah eksisting (SMP dan SMA) }\end{array}$ & $\begin{array}{l}\text { Data Pokok Pendidikan Dasar dan } \\
\text { Menengah Kabupaten Solok Selatan }\end{array}$ \\
\hline $\begin{array}{l}\text { c. Jumlah kelas eksisting (SMP dan } \\
\text { SMA) }\end{array}$ & $\begin{array}{l}\text { Dinas Pendidikan Tingkat Kabupaten } \\
\text { dan Provinsi }\end{array}$ \\
\hline $\begin{array}{l}\text { Peta administrasi Kabupaten Solok } \\
\text { Selatan }\end{array}$ & Bappeda Kabupaten Solok Selatan \\
\hline
\end{tabular}

Sumber: Peneliti, 2019 


\section{Teknik Pengumpulan Data}

Data yang dibutuhkan dikumpulkan secara langsung ke instansi terkait, karena data yang diperlukan adalah data sekunder.

\section{Teknik Analisis Data}

Teknik analisis data yang digunakan dapat dilihat pada tabel dibawah ini:

Tabel 2. Teknik Analisis Data Penelitian

\begin{tabular}{lll}
\hline Penelitian & Teknik analisis & Output \\
\hline Evaluasi Ketersediaan jumlah tingkat pelayanan fasilitas & Peta tingkat pemenuhan \\
fasilitas pendidikan eksisting pendidikan & kebutuhan dan keterisian \\
tingkat SMP dan SMA a) analisis & tingkat SMP dan SMA & \\
$\begin{array}{c}\text { Kabupaten Solok Selatan } \\
\text { b) analisis tingkat keterisian } \\
\text { sekolah }\end{array}$ &
\end{tabular}

Kebutuhan penduduk akan Proyeksi penduduk

Jumlah fasilitas pendidikan fasilitas pendidikan tingkat yang dibutuhkan

SMP dan SMA dimasa sekarang dan 20 tahun yang akan datang

\begin{tabular}{ll}
\hline Sebaranserta jangkauan Buffer & Peta sebaran fasilitas \\
fasilitas pendidikan tingkat & pendidikan serta jangkauan \\
SMP dan SMA saat sekarang & pelayanan tingkat SMP dan \\
& SMA
\end{tabular}

Setelah mengumpulkan data yang dibutuhkankemudian diolah sesuai dengan rumus-rumus yang diperlukan.

1. Evaluasi Keterediaan Fasilitas Pendidikan Eksisting Tingkat SMP dan SMA Kabupaten Solok Selatan

a. Kemampuan Daya Tampung kemampuan daya tampung dapat dilihat dengan membandingkan kelas eksisting dengan kebutuhan kelas minimum.

b. Kebutuhan Penduduk Terhadap Fasilitas Pendidikan merupakan perbandingan antara daya tampung dengan penduduk usia sekolah

c. Tingkat Keterisian Kelas
Tingkat keterisisan sekolah ini dapat digunkan untuk melihat apakah sekolah yang ada berada dalam kondisi undercapacity atau over capacity.

Persentase untuk tingkat pemenuhan dan keterisian kelas dinilai baik atau efisien apabila mencapai 80-110\%, dinilai cukup apabila persentase mencapai $>110$ dan dinilai kurang apabila hanya $<80 \%$.

2. Analisis Kebutuhan Penduduk Akan Fasilitas Pendidikan Tingkat SMP dan SMA Pada Masa Sekarang dan 20 Tahun Yang Akan Datang 
a. Daya Dukung Fasilitas

Ini dibutuhkan untuk melihat perbandingan sekolah yang tersedia dengan sekolah yang dibutuhkan.

b. Proyeksi Penduduk

Proyeksi penduduk total dibutuhkan untuk melihat kebutuhan sekolah berdasarkan ketetapan standard Permendiknas No 24 tahun 2007.

c. Proyeksi Penduduk Usia Sekolah: setelah diproyeksikan penduduk total maka perlu juga untuk dilihat berapa penduduk usia sekolah di tahun proyeksi dengan asumsi semua penduduk usia sekolah bersekolah semuanya pada tahun itu, atau dengan kata lain APM $100 \%$.

3. Sebaran Serta Jangkauan

Pelayanan Fasilitas Pendidikan Tingkat SMP Dan SMA Di Kabupaten Solok Selatan Pada Saat Sekarang

Sebaran sekolah eksisting yang dipetakan akan dibuffer dengan range $6 \mathrm{~km}$ untuk fasilitas pendidikan tingkat SMP sesuai dengan standar permendikans No 24 tahun 2007, sementara untuk SMA tidak perlu dilihat jangkauan pelayanan karena standar untuk SMA cukup satu sekolah perkecamatan

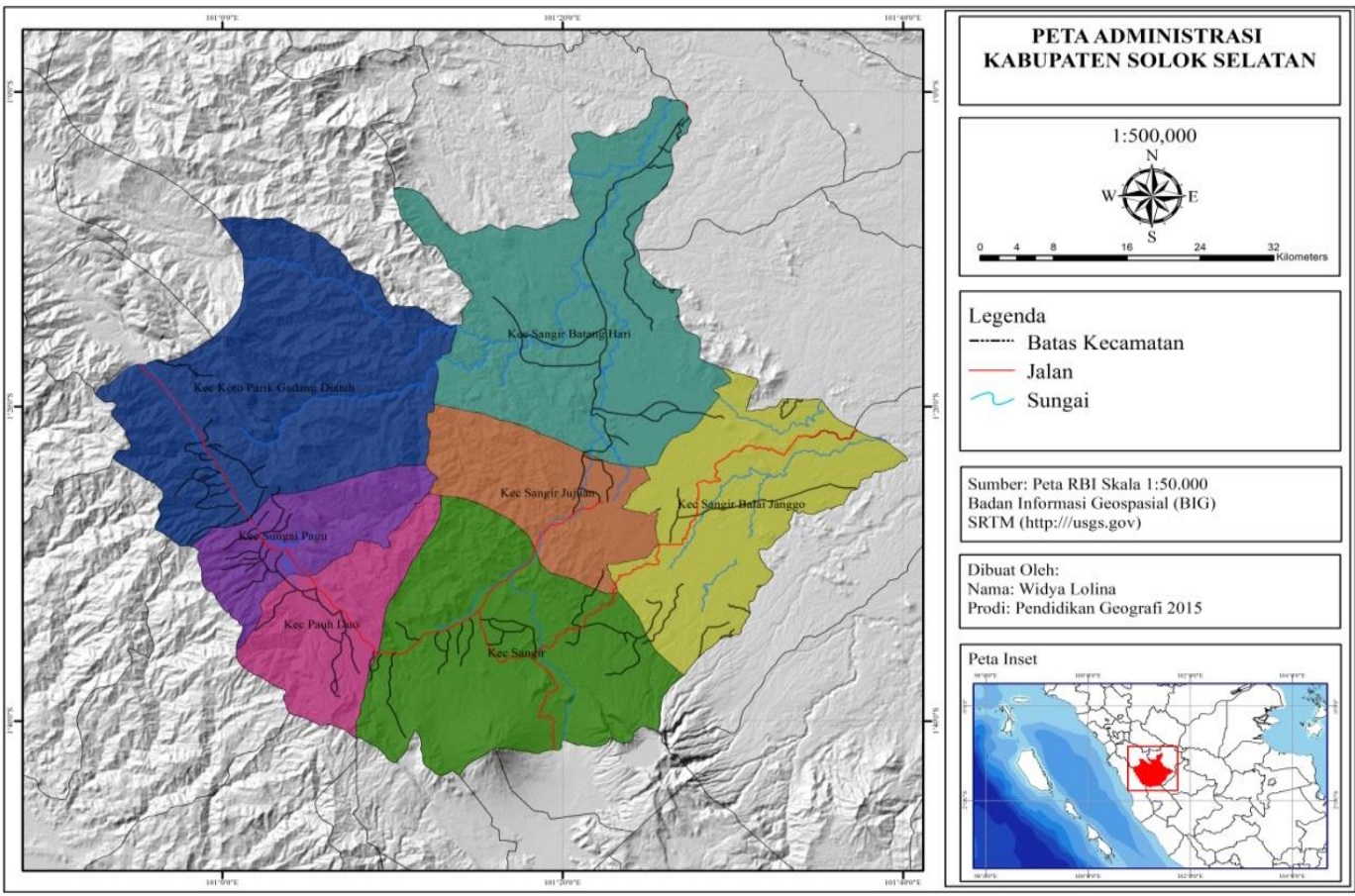

Gambar 1.Daerah Lokasi Penelitian 


\section{Diagram Alir Penelitian}

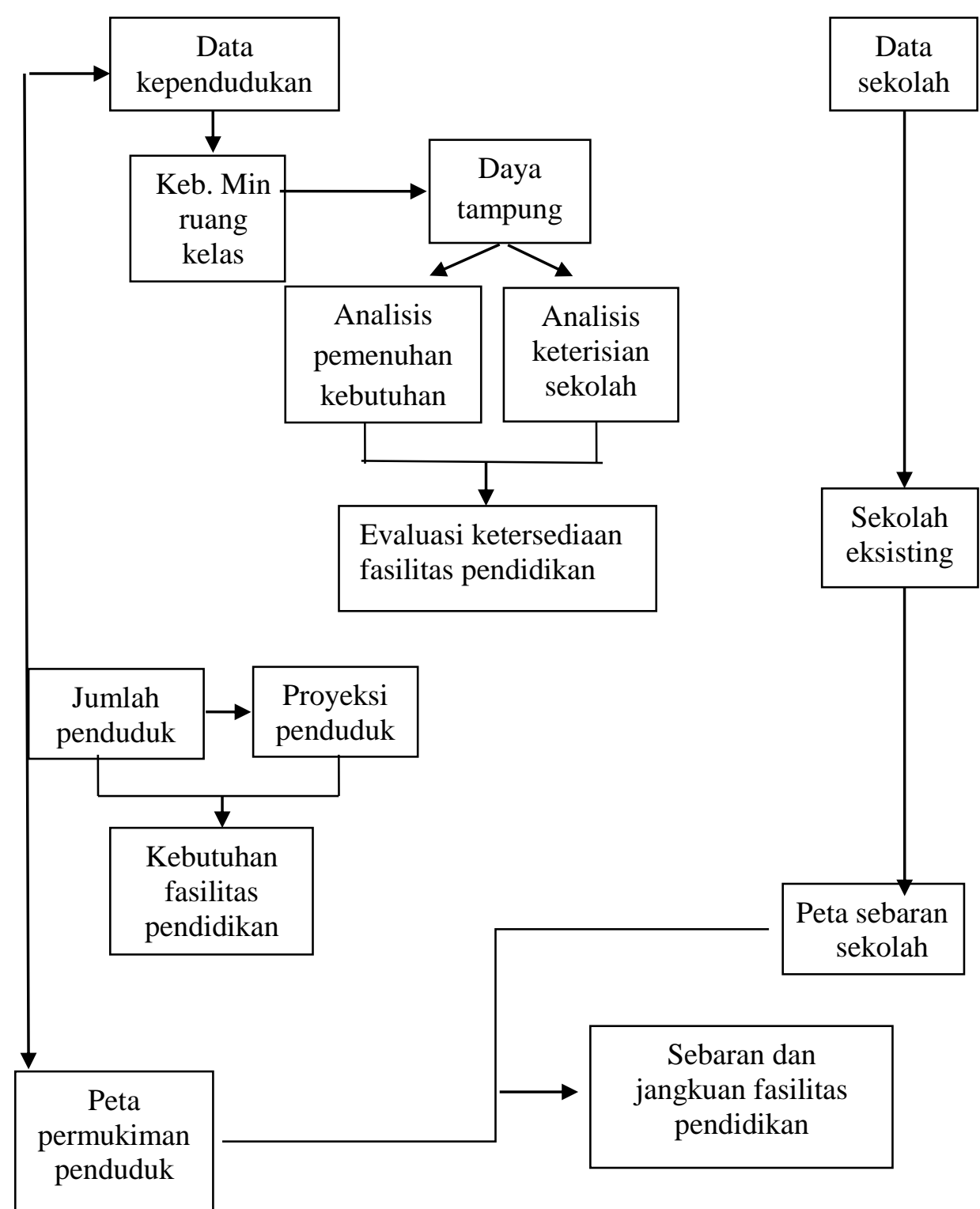

Gambar 2. Diagram Alir Penelitian

Hasil Penelitian

1. Evaluasi Ketersediaan Fasilitas Pendidikan Eksisting Tingkat SMP dan SMA di Kabupaten Solok Selatan
a. Analisis
Pemenuhan
Kebutuhan fasilitas pendidikan Tingkat SMP

Analisis ini dilakukan untuk melihat apakah sekolah yang ada sudah mencukupi sesuai dengan kebutuhan penduduk atau belum. Setelah dilakukan perhitungan evaluasi tentang kebutuhan penduduk usia sekolah terhadapfasilitas penduduk maka 
hasilnya dapat dilihat pada tabel dibawah:

Tabel 3. Analisis pemenuhan kebutuhan fasilitas pendidikan tingkat SMP

\begin{tabular}{lllll}
\hline \multicolumn{4}{c}{ Analisis pemenuhan kebutuhan tingkat SMP } \\
\hline Kec & Dt & PUS & Pk $(\%)$ & Kategori \\
\hline Sangir & 3629 & 2472 & 146,8 & Cukup \\
\hline Sangir jujuan & 1253 & 783 & 160 & Cukup \\
\hline SB. janggo & 1605 & 856 & 187,5 & Cukup \\
\hline S. Bt hari & 1460 & 973 & 150,1 & Cukup \\
\hline Sungai pagu & 2895 & 1737 & 166,6 & Cukup \\
\hline Pauh duo & 1394 & 981 & 142,1 & Cukup \\
\hline KPGD & 2271 & 1497 & 151,7 & Cukup
\end{tabular}

Sumber: peneliti, 2019

Tabel diatas menunjukkan bahwa fasilitas pendidikan yang ada disetiap kecamatan sudah mencukupi kebutuhan penduduk, karena daya tampung sekolah yang cukup besar sehingga dapat menampung penduduk usia sekolah dengan baik

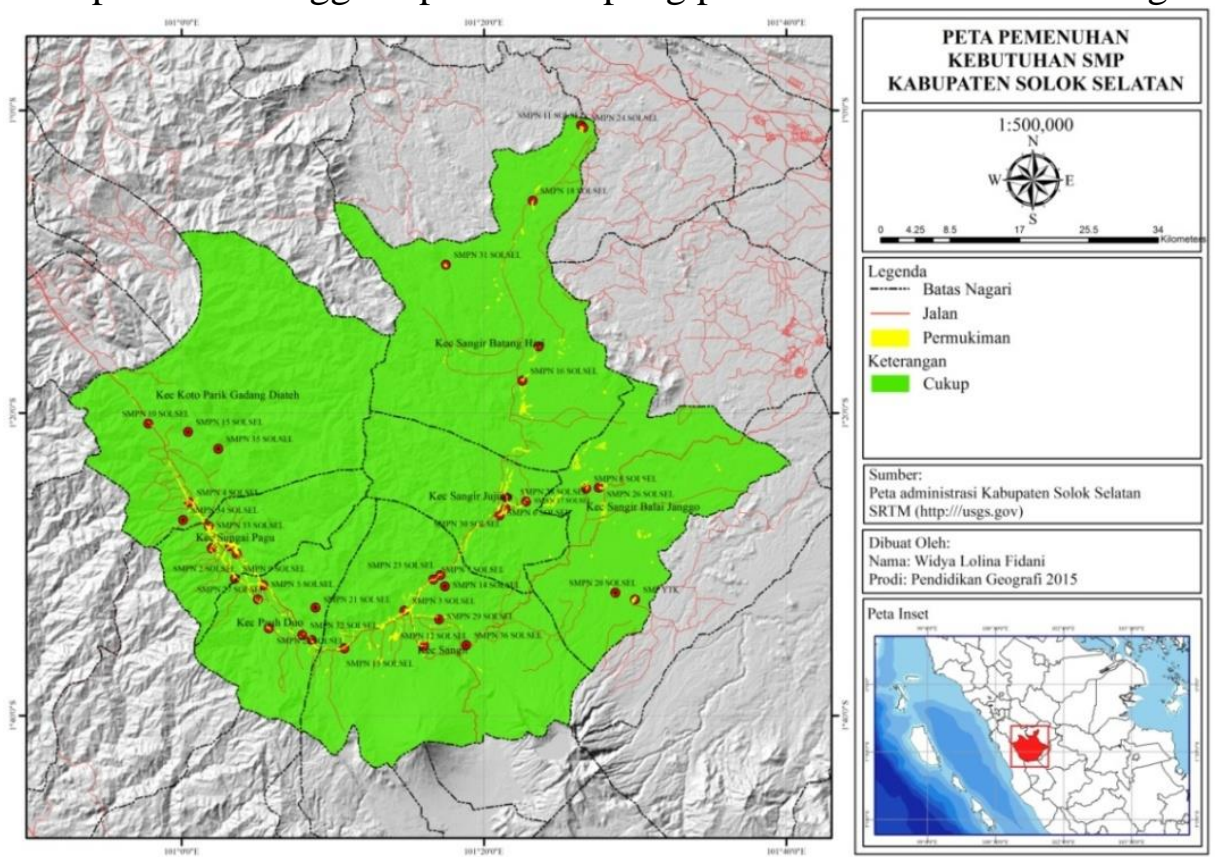

Gambar 3. Peta Analisis Pemenuhan Kebutuhan Fasilitas Pendidikan Tingkat SMP

b. Analisis Tingkat Keterisian Fasilitas Pendidikan Tingkat SMP

Tabel 4. Tingkat keterisian sekolah tingkat SMP

\begin{tabular}{lllll}
\hline \multicolumn{5}{c}{ Analisis tingkat keterisian sekolah tingkat SMP } \\
\hline Kecamatan & $\mathrm{M}$ & $\mathrm{Dt}$ & Tk $(\%)$ & Kategori \\
\hline Sangir & 1504 & 3629 & 41,4 & Kurang \\
\hline Sangir Jujuan & 428 & 1253 & 34,2 & Kurang \\
\hline Sangir Balai Janggo & 717 & 1605 & 44,7 & Kurang \\
\hline Sangir Batang hari & 623 & 1460 & 42,7 & Kurang \\
\hline Sungai pagu & 952 & 2895 & 32,9 & Kurang \\
\hline Pauh duo & 466 & 1394 & 33,4 & Kurang \\
\hline KPGD & 996 & 2271 & 43,9 & Kurang
\end{tabular}

Sumber: Peneliti, 2019 
Dari tabel diatas dapat dilihat bahwa semua kecamatan termasuk kedalam kategori kurang, karena jumlah

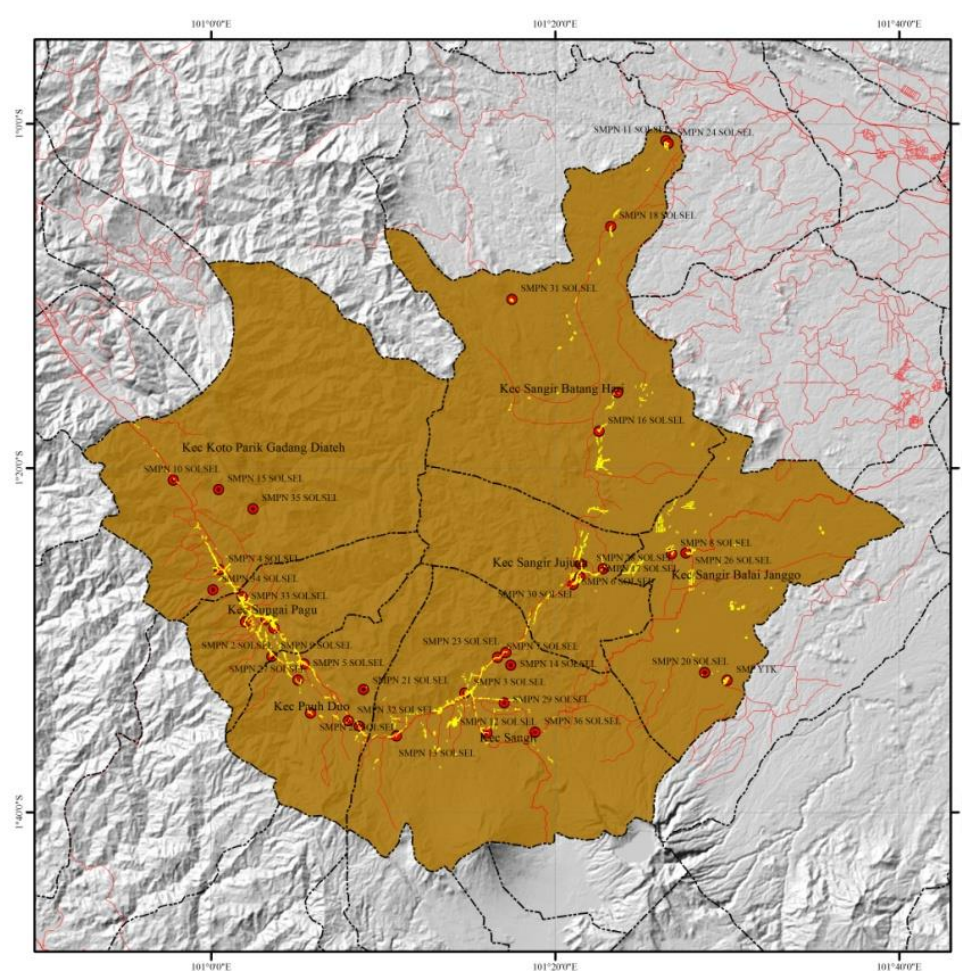

murid lebih sedikit dibandingkan dengan daya tampung yang ada.

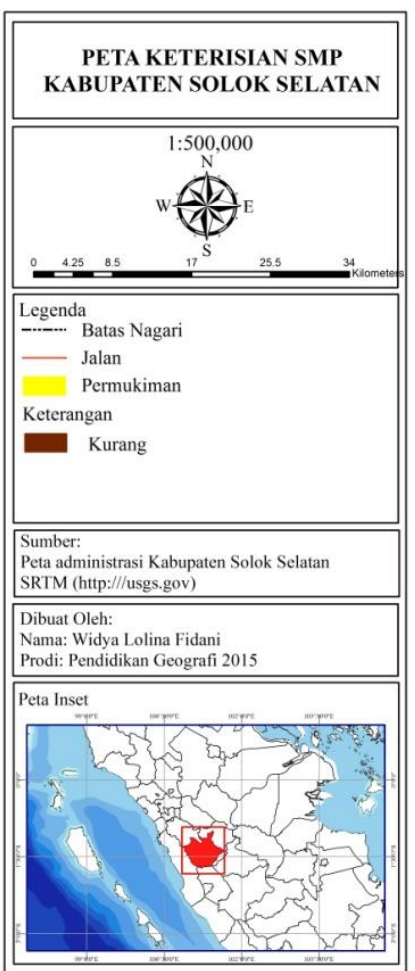

Gambar 4. peta analisis tingkat keterisian sekolah SMP

kebutuhan fasilitas pendidikan

c. Analisis Tingkat Pemenuhan Kebutuhan Fasilitias Pendidikan SMA

Setelah melihat tingkat kebutuhan fasilitas pendidikan untuk tingkat SMP maka selanjutnya adalah melihat tingkat untuk tingkat SMA dimasingmasing kecamatan.

Tingkat pemenuhan kebutuhan fasilitas pendidikan untuk tingkat SMA di masing-masing kecamatan dapat dilihat pada tabel dibawah ini:

Tabel 5. Pemenuhan kebutuhan tingkat SMA

\begin{tabular}{lllll}
\hline \multicolumn{5}{c}{ Analisis pemenuhan kebutuhan tingkat SMA } \\
\hline Kec & \multicolumn{1}{c}{ Dt } & \multicolumn{1}{c}{ PUS } & Pk $(\%)$ & \multicolumn{1}{c}{ Kategori } \\
\hline Sangir & 4125 & 2189 & 188 & Cukup \\
\hline Sangir Jujuan & 1669 & 751 & 222 & Cukup \\
\hline Sangir Balai Janggo & 257 & 772 & 33,3 & Kurang \\
\hline Sangir Batang Hari & 1964 & 854 & 230 & Cukup \\
\hline Sungai Pagu & 4168 & 1616 & 257,9 & Cukup \\
\hline Pauh Duo & 415 & 830 & 50 & Kurang \\
\hline KPGD & 1877 & 1306 & 143,7 & Cukup \\
\hline
\end{tabular}

Sumber: peneliti, 2019 
Dari tabel diatas dapat dilihat bahwa terdapat 5 kecamatan berkategori cukup, dan 2 kecamatan masuk kategori kurang. Kecamatan yang masuk kedalam kategori kurang dikarenakan daya tampung yang ada tidak mampu menampung jumlah penduduk usia sekolah yang ada.
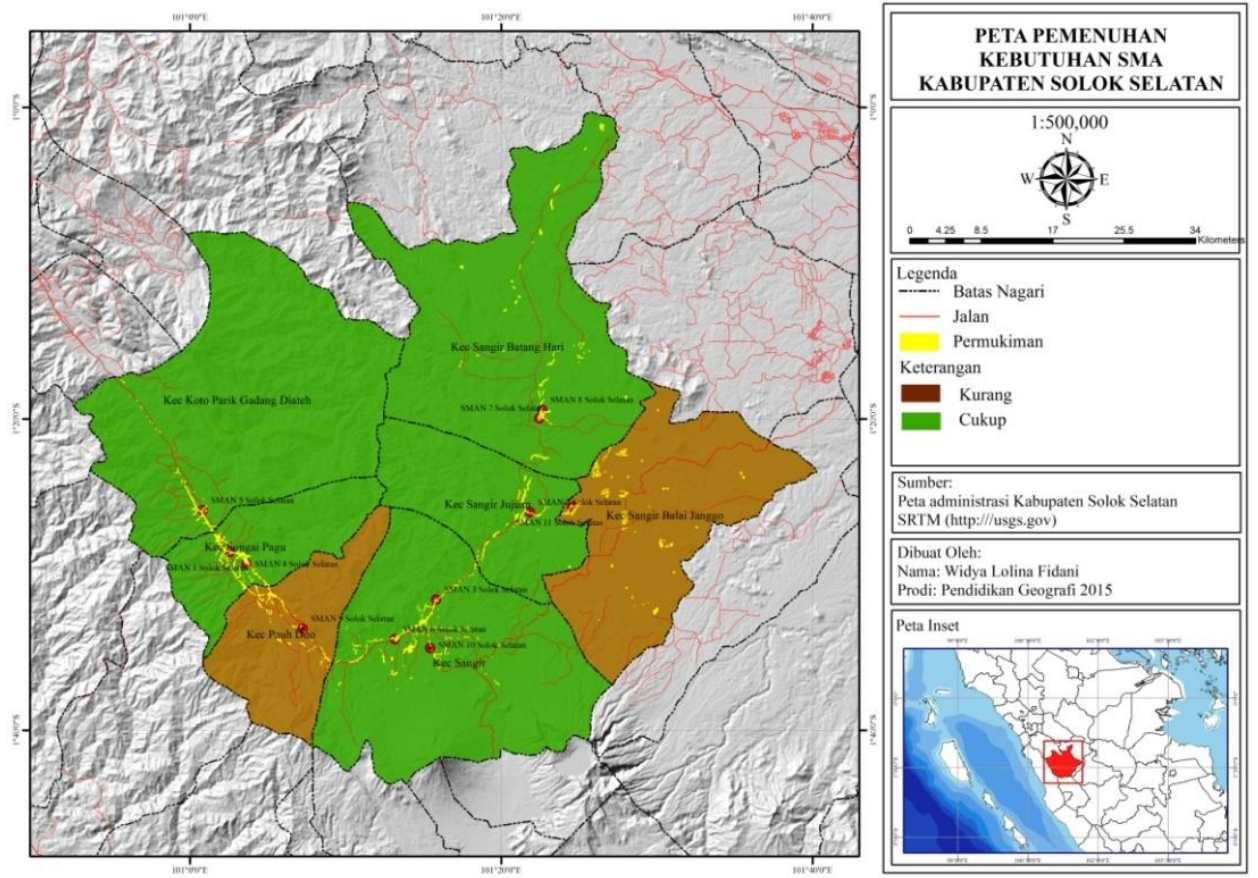

Gambar 5. Peta Analisis Pemenuhan Kebutuhan Fasilitas Pendidikan Tingkat SMA

d. Analisis tingkat keterisian sekolah SMA

Setelah dilakukan pengolahan data sekunder didapatkan hasilnya yaitu tingkat keterisian sekolah tingkat SMA setiap kecamatan termasuk kedalam kategori kurang, sama halnya dengan keterisian fasilitias pendidikan tingkat SMP yang semua kecamatan masuk kedalam kategori kurang. Hal ini terjadi karena walaupun penduduk usia sekolah banyak tetapi belum tetu mereka bersekolah seluruhnya, itulah yang mempengaruhi tingkat keterisian sekolah. Hal itu dapat dilihat pada tabel dibawah ini:

Tabel 6. Tingkat Keterisian Fasilitas PendidikanTingkat SMA

\begin{tabular}{lllll}
\hline \multicolumn{5}{c}{ Analisis tingkat keterisian fasilitas pendidikan tingkat SMA } \\
\hline Kec & M & Dt & Tk $(\%)$ & Kategori \\
\hline Sangir & 1052 & 4125 & 25,5 & Kurang \\
\hline Sangir Jujuan & 383 & 1669 & 22,9 & Kurang \\
\hline Sangir Balai Janggo & 54 & 257 & 21 & Kurang \\
\hline Sangir Batang Hari & 377 & 1964 & 19,2 & Kurang \\
\hline Sungai Pagu & 1423 & 4168 & 34,1 & Kurang \\
\hline Pauh Duo & 82 & 415 & 19,8 & Kurang \\
\hline KPGD & 677 & 1877 & 36,1 & Kurang
\end{tabular}

Sumber: peneliti, 2019 

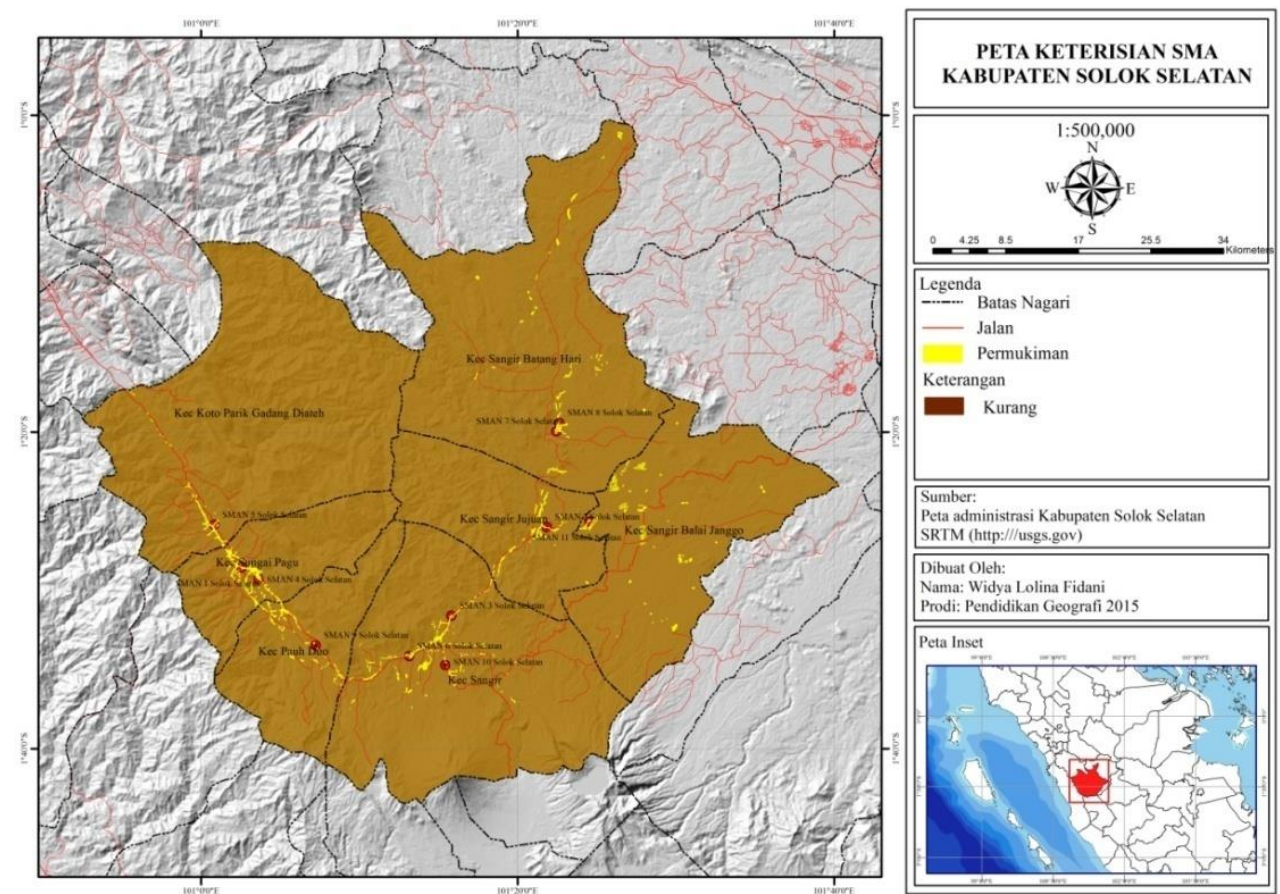

Gambar 6. Peta Analisis Keterisian Sekolah Tingkat SMA

Kebutuhan fasilitas ini

2. Kebutuhan

akanFasilitas

Tingkat SMP dan SMA pada

Masa Sekarang dan 20 tahun

Mendatang di Kabupaten

Solok Selatan penduduk

Pendidikan

ditinjau dari kebutuhan penduduk total sesuai dengan standard yang ditetapkan permendiknas no 24 tahun 2007. Berikut adalah kebutuhan fasilitas pendidikan pada saat sekarang

Tabel 7. kebutuhanfasilitas pendidikan tingkat SMP dan SMA dimasa sekarang

\begin{tabular}{llllllll}
\hline \multicolumn{7}{c}{ Kebutuhan fasilitas pendidikan pada masa sekarang } \\
\cline { 2 - 9 } kecamatan & Jml.pdd & Keb & Eks & $(-)$ & Keb & Eks & $(-)$ \\
\hline Sangir & 43.485 & 21 & 8 & 13 & 7 & 3 & 4 \\
\hline Sangir jujuan & 14.330 & 7 & 4 & 3 & 2 & 1 & 1 \\
\hline Sangir balai janggo & 21.166 & 10 & 4 & 6 & 3 & 1 & 2 \\
\hline Sangir batang hari & 17.594 & 8 & 6 & 2 & 3 & 2 & 1 \\
\hline Sungai pagu & 31.148 & 15 & 5 & 10 & 4 & 2 & 3 \\
\hline Pauh duo & 16.822 & 8 & 6 & 2 & 2 & 1 & 1 \\
\hline KPGD & 25.122 & 12 & 5 & 7 & 4 & 1 & 3 \\
\hline Jumlah & 169.667 & 81 & 38 & 43 & 26 & 11 & 15 \\
\hline
\end{tabular}

Sumber: peneliti, 2019

Tabel diatas menunjukkan membutuhkan 43 SMP dan 15

Kabupaten Solok Selatan saat ini SMA. 
Untuk mengetahui berapa tahun proyeksi, berikut hasil proyesi kebutuhan fasilitas pendidikan solok penduduk kabupaten solok selatan selatan ditahun proyeksi maka perlu 2039:

dilihat berapa jumlah penduduk di

Tabel 8. Proyeksi penduduk secara keseluruhan

\begin{tabular}{llll}
\hline \multicolumn{4}{l}{ Proyeksi penduduk secara keseluruhan } \\
\hline Kec & $\mathrm{P} 0$ & $(1+\mathrm{r})^{\mathrm{n}}$ & $\mathrm{P}$ \\
\hline Sangir & 43.485 & 1,54 & 67.328 \\
\hline Sangir Jujuan & 14330 & 1,99 & 28.592 \\
\hline Sangir Balai Janggo & 21166 & 4,29 & 90.981 \\
\hline S.Sb. hari & 20781 & 1,7 & 36.563 \\
\hline Sungai pagu & 32676 & 1,24 & 40.825 \\
\hline Pauh duo & 16822 & 2,06 & 34.809 \\
\hline KPGD & 25122 & 1,55 & 39.048 \\
\hline Total & & & 338.149
\end{tabular}

Sumber: Penliti, 2019

Tabel 9. Proyeksi penduduk usia sekolah tingkat SMP dan SMA 2039

\begin{tabular}{lllllll}
\hline \multicolumn{2}{l}{ Proyeksi penduduk 13-15 tahun } & & $\begin{array}{l}\text { Proyeksi } \\
\text { tahun }\end{array}$ & penduduk & $16-18$ \\
\hline Kec & $\mathrm{P} 0$ & $(1+\mathrm{r})^{\mathrm{n}}$ & $\mathrm{P}$ & $\mathrm{P} 0$ & $(1+\mathrm{r})^{\mathrm{n}}$ & $\mathrm{P}$ \\
\hline Sangir & 2472 & 1,22212 & 3.021 & 2189 & 1,005 & 2.435 \\
\hline Sangir jujuan & 783 & 1,4912 & 1168 & 751 & 1,014 & 1.010 \\
\hline S. B.janggo & 856 & 1,9272 & 1650 & 772 & 1,028 & 1.341 \\
\hline S.Bt. hari & 973 & 1,8694 & 1819 & 854 & 1,026 & 1.452 \\
\hline Sungai pagu & 1737 & 1,0670 & 1853 & 1616 & 0,998 & 1.564 \\
\hline Pauh duo & 981 & 1,1775 & 1155 & 830 & 1,002 & 1.877 \\
\hline KPGD & 1497 & 1,1225 & 1680 & 1306 & 1,000 & 1.326 \\
\hline TOTAL & & & 12.346 & & & 10.006
\end{tabular}

Sumber: Peneliti,2019

Tabel 10. Kebutuhan dan ketersediaan fasilitas pendidikan tingkat SMP tahun proyeksi

\begin{tabular}{llllllll}
\hline \multicolumn{7}{l}{ Analisis kebutuhan dan ketersediaan fasilitas pendidikan tingkat SMP tahun proyeksi } \\
\hline Kecamatan & $(13-15 \mathrm{Th})$ & $\mathrm{Dt}$ & Kkrgn Dt & ekst & Min & $(+)(-)$ & rombel \\
\hline Sangir & 3021 & 3629 & +608 & 8 & 33 & -25 & 94 \\
\hline $\begin{array}{l}\text { Sangir } \\
\text { jujuan }\end{array}$ & 1168 & 1253 & +11 & 4 & 14 & -10 & 36 \\
\hline S.B.Janggo & 1650 & 1605 & -45 & 4 & 44 & -40 & 51 \\
\hline S.Bt. hari & 1819 & 1460 & -359 & 6 & 18 & -12 & 56 \\
\hline Sungai pagu & 1853 & 2895 & +1042 & 5 & 20 & -15 & 57 \\
\hline Pauh duo & 1155 & 1394 & +239 & 6 & 17 & -11 & 36 \\
\hline KPGD & 1480 & 2271 & +591 & 5 & 19 & -14 & 52 \\
\hline TOTAL & 12.346 & 14.570 & & 38 & 165 & -127 & 382 \\
\hline
\end{tabular}

Sumber: Peneliti. 2019 
Tabel 11. kebutuhan dan ketersediaan fasilitas pendidikan tingkat SMA tahun proyeksi

\begin{tabular}{llllllll}
\hline \multicolumn{6}{c}{ Analisis kebutuhan dan ketersediaan fasilitas pendidikan tingkat SMA tahun proyeksi } \\
\hline Kecamatan & $\begin{array}{l}16-18 \\
\text { tahun }\end{array}$ & Dt & Kkrg Dt & Eks & Min & $(+)(-)$ & Rombel \\
\hline Sangir & 2435 & 4125 & +1690 & 3 & 11 & -8 & 67 \\
\hline S. jujuan & 1010 & 1669 & +659 & 1 & 4 & -3 & 28 \\
\hline S.B.janggo & 1341 & 257 & -1084 & 1 & 14 & -13 & 37 \\
\hline S.Bt. hari & 1452 & 1964 & 512 & 2 & 6 & -4 & 40 \\
\hline Sungai pagu & 1564 & 4168 & +2604 & 2 & 6 & -4 & 43 \\
\hline Pauh duo & 877 & 415 & -462 & 1 & 5 & -4 & 24 \\
\hline KPGD & 1326 & 1877 & +551 & 1 & 6 & -5 & 36 \\
\hline TOTAL & 10.006 & 14.476 & 3913 & 11 & 53 & -41 & 275 \\
\hline
\end{tabular}

Sumber: Peneliti. 2019

Dari tabel diatas dapat dilihat bahwa dari tahun proyeksi kebutuhan penduduk akan bangunan sekolah untuk tingkat SMP sebanyak 127 sekolah, sementara untuk SMA butuh 41 unit sekolah lagi. Penentuan jumlah kebutuhan ini didasarkan pada Permendiknas No 24 tahun 2007 yang menetapkan standar penduduk maksimal yang harus dilayani oleh satu unit sekolah.

3. Sebaran Serta Jangkauan Pelayanan Fasilitas Pendidikan Tingkat SMP dan SMA di Kabupaten Solok Selatan Saat Sekarang

Hasil proses buffering menunjukkan bahwa masih dapat permukiman yang berada diluar buffer sekolah sehingga masih ada permukiman yang tidak mendapatkan pelayanan untuk mendapatkan fasilitas pendidikan dengan baik, akibatnya mereka harus menempuh perjalanan ke sekolah lebih jauh dibandingkan dengan permukiman yang masih berada didalam lingkar range buffer. Beberapa kecamatan yang sebaran dan jangkauan fasilitas pendidikan yang tidak merata yaitu Kecamtan Koto Parik Gadang Diateh, Kecamatan Sangir Jujuan, Kecamatan Sangir Batang Hari Dan Kecamatan Sangir Balai Janggo. Sedangkan untuk SMA tidak dilakukan proses buffer karena terkhusus untuk SMA hanya ditetapkan minimal satu SMA perkecamatan. 

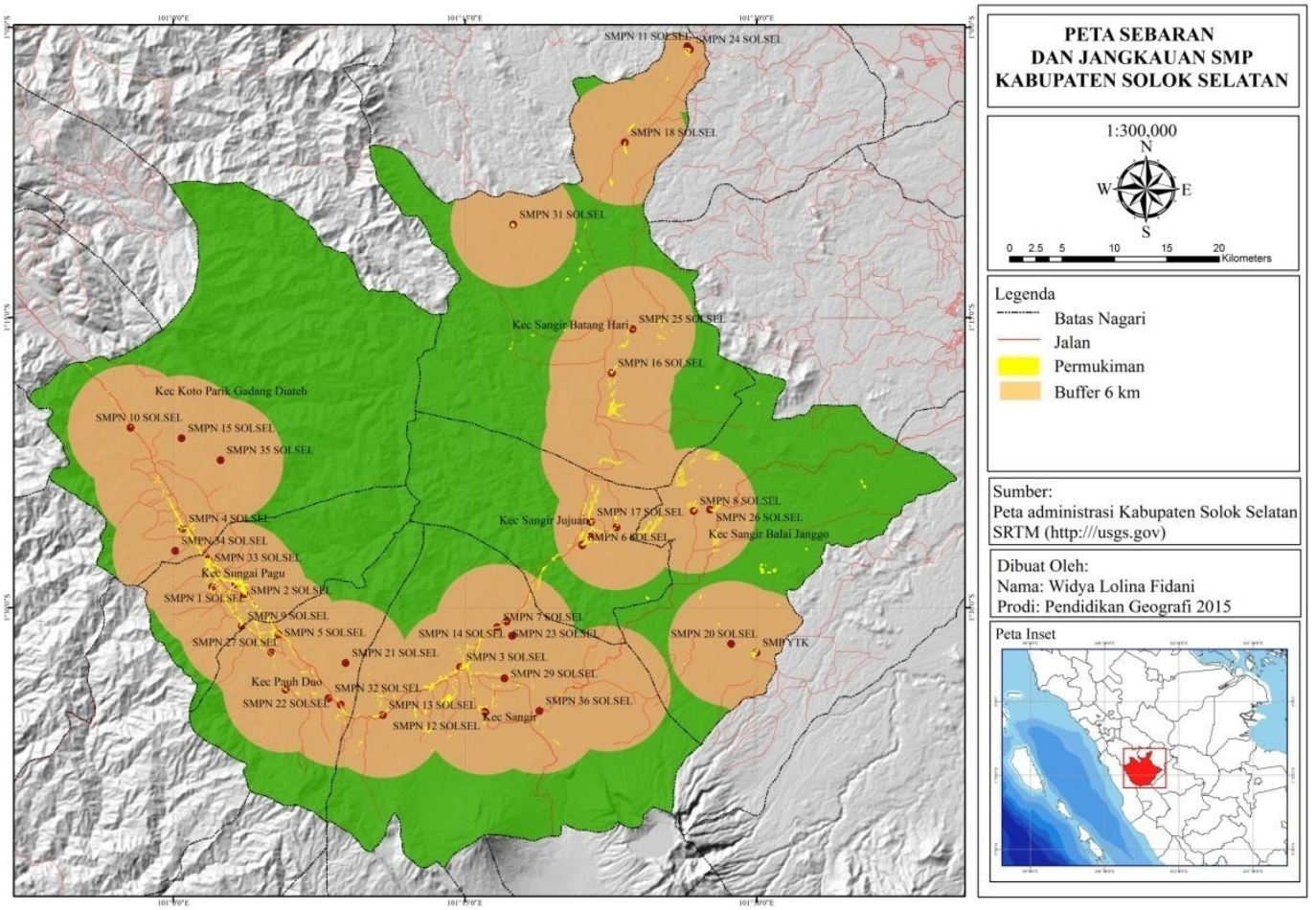

Gambar 7. Sebaran serta jangkauan pelayanan SMP kabupaten solok selatan

\section{Kesimpulan}

Ketersediaan fasilitas pendidikan yangdilihat dari segitingkat pelayanannya, maka untuk tingkat pemenuhan, maka untuk tingkat pemenuhan kebutuhan fasilitas pendidikan tingkat SMP, semua kecamatan termasuk kedalam kategori cukup, dalam artian kebutuhan penduduk usia sekolah akan fasilitas pendidikan untuk tingkat SMP tercukupi. Selanjutnya untuk tingkat keterisisan, seluruh kecamatan termasuk kedalam kategori kurang, hal ini berarti terjadi undercapacity dalam menampung penduduk usia sekolah dimasingmasing kecamatan.

Sementara untuk tingkat pemenuhan kebutuhan untuk jenjang SMA, lima kecamatan berkategori cukup, dua kecamatan berkategori kurang, yaitu kecamatan Sangir Balai Janggo dan Pauh Duo yang berarti kebutuhan penduduk akan fasilitas pendidikan di dua kecamatan tersebutbelum terpenuhi. Sementara untuk tingkat keterisian semua kecamatan termasuk kedalam kategori kurang.

Jika dilihat dari segi pemenuhan kebutuhan sekolah pada saat ini, rataratasemua kecamatan termasuk kedalam kategori cukup, karena adanya keseimbangan antara daya tampung dengan penduduk usia sekolah, namun tingkat keterisian sekolah bisa jadi berubah kategori menjadi kurang efisien hal ini dikarenakan semua penduduk usia sekolah belum tentu bersekolah 
seluruhnya sehingga tidak bisa seimbang dengan daya tampungnya.

Kebutuhan sekolah 20 tahun mendatang untuk tingkat SMP sebanyak 127 sekolah dan untuk SMA 41 sekolah. Ada baiknya sekolah-sekolah yang sudah ada tetapi belum sesuai dengan kriteria Permendiknas No 24 tahun 2007 melengkapi sarana yang kurang seperti rombongan belajar yang

\section{Daftar Pustaka}

Badan Pusat Statistik. (2019). Solok Selatan Dalam Angka 2018. Solok Selatan. BPS.

Badan Pusat Statistik. (2018). Solok Selatan Dalam Angka 2017. Solok Selatan. BPS

Husaeini, Usman. 2006. Manajemen:

Teori, Praktik, Dan Riset Pendidikan. Jakarta: Bumi Aksara

Muta'ali, Luthfi. 2015. Teknik Analisis Regional Untuk Perencanaan Wilayah, Tata Ruang, Dan Lingkungan. Yogyakarta: Badan Penerbit Fakultas Geograf

Mantra, Ida Bagoes. 2003. Demografi Umum. Yogyakarta: Pustaka Belajar

Husaeini, Usman. 2006. Manajemen Pendidikan : Teori, Kebijakan, Dan Praktik. Jakarta: Bumi Aksara.

Hapon Ch Gewab, Andi A Malik, \&Henriek H Karongkong. (2015). Analisis Kebutuhan Dan Sebaran Fasilitas masing belum mencapai kapasitas maksimal ditambah lagi sehingga tidak perlu penambahan sekolah, cukup penambahan bangunan baru saja untuk dapat menampung seluruh penduduk usai sekolah.

Pendidikan Tingkat SMP Dan SMA Di Kabupaten Tambrau. Universitas Sam Ratulangi

Lampiran Peraturan Menteri Pendidikan Nasional Republik Indonesia No 24 Tahun 2007 Tentang Satndar Sarana Dan Prasarana Untuk Sekolah Dasar/Madrasah Ibtidaiyah (SD/MI), Sekolah Menengah Pertama Aliyah (SMP/Mts), Dan Sekolah Menengah Atas, Sekolah Menengah Kejuruan Atau Bentuk Lain Yang Sederajat. Permendiknas RI

UU RI No 20 tahun 2003 tentang sistem pendidikan nasional. 